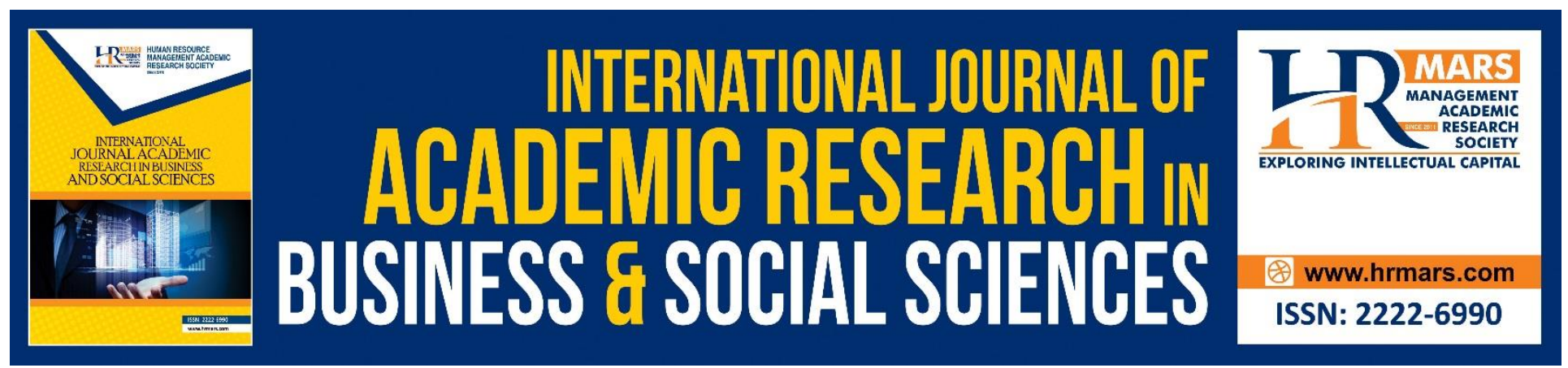

\title{
Language and Communication Achievements of Two, Three and Four Years Old Children in Childcare Centre
}

Zainiah Mohamed Isa, Mazlina Che Mustafa, Juppri Bacotang, Md Azman Shahadan, Suzani Mohamad Samuri, Bahbibi Rahmatullah, Norazilawati Abdullah, Grace Annammal Gnana Piragasam, Nurul 'Ain Hidayah Abas, Aslina Saad

To Link this Article: http://dx.doi.org/10.6007/IJARBSS/v8-i12/5515 DOI: $10.6007 /$ IJARBSS/v8-i12/5515

Received: 08 Nov 2018, Revised: 11 Dec 2018, Accepted: 28 Dec 2018

Published Online: 30 Dec 2018

In-Text Citation: (Isa et al., 2018)

To Cite this Article: Isa, Z. M., Mustafa, M. C., Bacotang, J., Shahadan, M. A., Samuri, S. M., Rahmatullah, B., ... Saad, A. (2018). Language and Communication Achievements of Two, Three and Four Years Old Children in Childcare Centre. International Journal of Academic Research in Business and Social Sciences, 8(12), 24182427.

\section{Copyright: (c) 2018 The Author(s)}

Published by Human Resource Management Academic Research Society (www.hrmars.com)

This article is published under the Creative Commons Attribution (CC BY 4.0) license. Anyone may reproduce, distribute, translate and create derivative works of this article (for both commercial and non-commercial purposes), subject to full attribution to the original publication and authors. The full terms of this license may be seen at: http://creativecommons.org/licences/by/4.0/legalcode

Vol. 8, No. 12, 2018, Pg. 2418 - 2427 


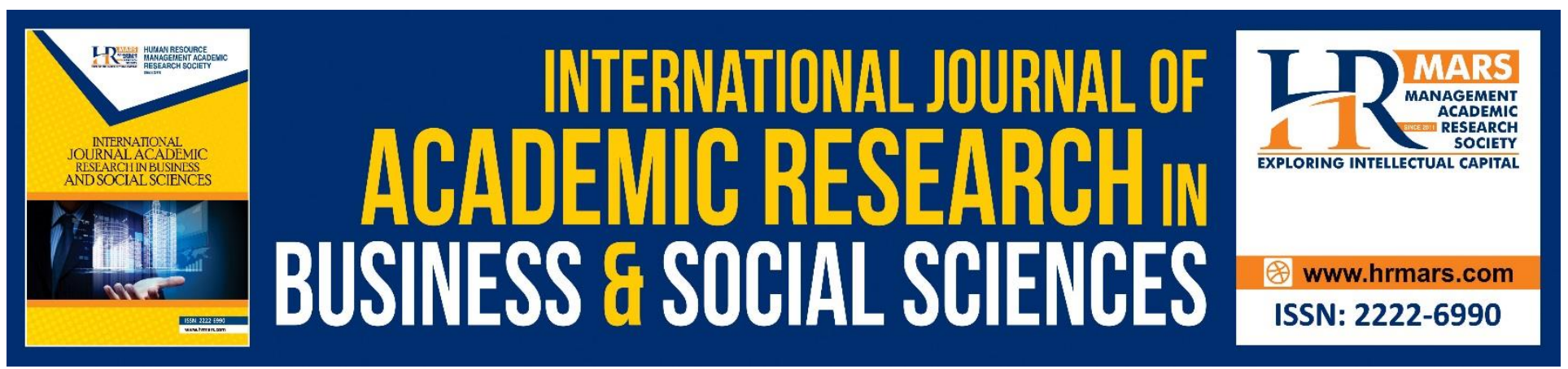

\title{
Language and Communication Achievements of Two, Three and Four Years Old Children in Childcare Centre
}

\author{
Zainiah Mohamed Isa ${ }^{1,2}$, Mazlina Che Mustafa ${ }^{1,2}$, Juppri Bacotang ${ }^{1,2}$, \\ Md Azman Shahadan ${ }^{1}$, Suzani Mohamad Samuri², Bahbibi \\ Rahmatullah', Norazilawati Abdullah ${ }^{1,2}$, Grace Annammal Gnana \\ Piragasam ${ }^{1,2}$, Nurul 'Ain Hidayah Abas ${ }^{1,2}$, Aslina Saad² \\ Faculty of Human Development, Universiti Pendidikan Sultan Idris ${ }^{1}$ \\ National Child Development Research Centre (NCDRC), Universiti Pendidikan Sultan Idris ${ }^{2}$ \\ Email: zainiah@fpm.upsi.edu.my
}

\begin{abstract}
Language and communication development for young children consist of four components, which are vocabulary, syntax, semantic, and communication. The purpose of this study is to determine language and communication achievements of 2, 3 and 4 years old children. This study involves 1000 children from 65 childcare centers in one of the states in Malaysia. This study uses a survey method, by using National Database to identify language and communication development of 2+, 3+, and 4+ years old children. Findings of 2 years old indicate a low performance in all components. Only 17.9 percent of them has achieved the skills of make a sentence using two words (syntax). The findings for 3 years old children indicate that $50 \%$ to $60 \%$ attained the achievement's standard. However, only 50.6 percent of the children in this study has achieved the skills of using two to three words in a sentence. Findings for 4 years old children indicate that not more than $50 \%$ of children attained the achievement's standard required. The result also highlighted that the lowest achievement of communication that is $\mathbf{1 7 . 9}$ percent for 4 years old children. Overall results from this study, found that children are behind their achivement standard in all components of language and communication when compared to the achievement standard for their age group. Therefore, the implication of this study is to focus on the teachers and parents involvement to support childrens' language development as they are very much involved in childrens' early years of development. Teachers need to be trained on how to create language rich environment, initiate interactive conversation, and reading time with children in the classroom. On the other hand, parents need to communicate more with their children through daily activities and have reading time as a routine at home.
\end{abstract}

Keywords: Young Children, Child Care, Nursery, Language Development, Communication 


\section{INTRODUCTION}

Language and communication plays an important role in human development. Without language and communication skills, it is difficult for individuals to build competencies in other areas of development. Promoting communication and language development among infants and toddlers is important, as research has shown that greater language exposure and usage are essential to promote appropriate social interaction and cognitive development of young children. As The Early Catastrophe implied, children from as early as three years of age, showed a fundamentally different neurodevelopment, trajectories that would mark their educational future, and their socioeconomic potential. Well-developed language abilities help children to be successful in academics and to be able to communicate better with others. Without language and communication skills, children are at risk of literacy, academic, social, and emotional difficulties. When they become adults, they are at risk of unemployment and poor mental health (Mc Kean et al., 2015). Therefore, educators play an important role to support the development of language and communication since they are young. Consequently, the application of developmental checklist is critical to assess children's language and communication progress, and to plan for their support and intervention.

As to serve these purpose, National Child Development Research Centre (NCDRC) and Sultan Idris Education University (UPSI) has developed an integrated database in Malaysia, namely National Child Data Centre (NCDC). This database keeps comprehensive data on children, educators and childcare centres (TASKA) to facilitate stakeholders to plan and implement programs that are structured and comprehensive in line with National Children's Care and Early Childhood Care Policy, and for teachers and parents to keep track of children's development progress. The developmental checklist, which is for babies until 4 years old children, covers all areas of development including language and communication.

\section{OBJECTIVE AND RESEARCH QUESTIONS}

\section{Research Objective:}

To determine language and communication achievements of children aged 2, 3 and 4 years old in this study.

\section{Research Question:}

What are the achievements of language and communication development among children aged 2, 3 and 4 years old children?

\section{RESEARCH SIGNIFICANCE}

There are the needs to distinguish language and communication development skills of children in Malaysia. Findings from the study will give information children's language and communication achievement as not much study has been done in this area. Findings from this study will indicate children's performance according to the standard. This study enables policy makers to take measures based on the results. 


\section{RESEARCH LIMITATIONS}

This study only involves only 3000 children from 65 goverment childcare centers in one of the states in Malaysia. However, the number of children in the database is 52539 children from 4836 Childcare centre for the whole country. Due to the data cleaning process that take a lot of time and funding, only 1000 samples are included in the study. Therefore, the sample of the study is not representative for the larger population because the researcher uses purposive sampling. Consequently, the findings of this study cannot be generalized to all children aged $2+, 3+$, and $4+$ years in Malaysia. The data excludes information on social economic standards and parent's information. Thus, the results will not analyse the relationship between development skills and social economic status.

\section{RESEARCH METHODS}

This study uses a survey method to identify language and communication development of children age of $2+, 3+$, and $4+$ years old. The sample selection method is based on the sampling purpose of the researcher selecting the sample of the study under one agency in a state. This agency is selected based on its data competency which has been captured by NCDC system. Language and communication skills data of 3000 children aged 2+, 3+ and 4+ years old were selected for analysis. The language and communication skills items are Communication, Vocabulary, Syntax and Semantics. These checklists were developed by early childhood specialists to assess children's language and communication development based on their age standards.

\section{LITERATURE REVIEW \\ Language Development}

Even though children vary in their development of speech and language, children are expected to follow the language development milestones that are language and communication standards according to age groups. The milestones are identifiable skills that can serve as a guide to normal development which indicate a general age and time when most children pass through these periods. These milestones help teachers and parents to determine when a child may need extra help to learn to speak or to use language.

According to Jalongo, (2014) children aged 2 years old have great strides in receptive language and use telegraphic speech that consist of two or three words utterances. By 3 years old children are considered to be in the most rapid period of language growth and they attempt to communicate. By 4 years old their pronunciation and grammar improve and they begin to adjust their speech to the listener's information needs.

\section{Language and Communication Skills}

According Malec, Peterson and Elshereif (2017), the meaning of oral language is language form (vocabulary and syntax), semantics (narrative and comprehension), and pragmatics or communicative competence. Hence, to assess language and communication development is to measure it through the four language components mentioned above, which are vocabulary, syntax, semantics, and communication. 


\section{Communication}

Communication development for young children is the skills to understand and to express thoughts, feelings, and information. During early years, families and teachers play important roles for the development of children's communication skills (Gooden \& Kearns, 2013).

According to Lofland (2013), communication consists of four stages, which are; own agenda, requester, early communicator and partner. At the beginning stage, children communicate by body language, next they will understand simple and familiar sentences, then in advance stage they are able to use words or other methods of communication to request, protest, greet, gain your attention, ask and answer questions. Subsequently, they will start to use words or other means of communication to talk about the past and future, to express feelings, or to pretend. As a result, children's communication skills can be monitored through their oral communication such as making requests and conversations.

Having good communication skills will benefit children as they can communicate with the persons in their world and to have their needs met (Gooden \& Kearns, 2013). The expression of communication or a child's language begins with physical movements, gesture and later on using words, sentences, and conversations. It is essential that a child has one of these functional means of expressive language before going to kindergarten (Gooden \& Kearns, 2013).

\section{Vocabulary}

Vocabulary is knowledge of words' meanings that children develop since they are young (Christ \& Wang, 2010). Children usually utter their first words when they are about 1 year old (Conti-Ramsden \& Durkin, 2012).

Vocabulary consists of receptive language and expressive language. Receptive language develops earlier than expressive language. Hence, children will be able to understand meaning before they could say the words. The assessment of receptive language can be executed by asking children to point to pictures of objects and actions that adults named, and for expressive language, it was assessed when children named objects and actions in pictures (Neuman \& Dwyer, 2009; Malec et al., 2017).

Vocabulary development is important for young children as many research showed there are correlation between vocabulary and children's abilities to understand and communicate with others (Marchman \& Fernald, 2008; Malec et al., 2017). Being able to communicate and understand the meaning enable children to learn and voice out their needs, which is important for cognitive and social emotional development.

\section{Syntax}

Syntax is a study of word orders and rules (Machado, 2016) that involves grammar which happens when children gain more control of their language (Clay, 1993; Machado, 2016). Syntax enables 
INTERNATIONAL JOURNAL OF ACADEMIC RESEARCH IN BUSINESS AND SOCIAL SCIENCES

Vol. 8, No. 12, Dec, 2018, E-ISSN: $2222-6990$ C 2018 HRMARS

children to use language according to the language structure that makes easier for other people to understand what is being said.

To assess this skills, the review by Malec et al. (2017) suggests that, narratives can provide information about children's use of syntax through numbers of words, numbers of utterance and language complexity to indicate language productivity (Terry, Mills, Bingham, Mansour \& Marencin, 2013). Usually, for beginners, children will start with single word and as they grew up, number of words increase and sentence becomes more complex as they started to notice about language structure usage by adults.

Syntax also plays important role as it correlates with children overall language growth (Craig \& Washiton, 1994; Malec et al., 2017) and children's reading achievement (Craig, Connor, \& Washinton, 2003; Malec et al., 2017).

\section{Semantic}

Semantics is the study of meaning and acquisition of vocabulary (Machado, 2016) which is important for children's oral language comprehension and process of constructing knowledge.

Research by Borovsky, Ellis, Evans and Elman (2016) showed that 2 year olds had already begun to preactivate coordinating semantic information associated with the target noun while the verb was spoken. However, for young children, mental representation of early semantic relation is established earlier than speech (Capone, 2007). Therefore, to assess their understanding of the language spoken is when children can respond to instructions, which indicates their understanding of the language.

Semantic information from words and sentences are easily integrate with world knowledge and perceptual cues (Hagoort, Hald, Bastiaansen, \& Petersson, 2004 in Tribushinina, 2013). Therefore children's abilities of word aqusitions and understanding its meaning are the basis of building up knowledge about the world around them. Without these skills children are unable to learn new concepts of subject matter which are important for academic success.

Accordingly, assessment of preschool children requires various components to construct a profile of the child's language abilities. Measures of a single dimension are inadequate in determining the nature of a child's difficulties as they are less reliable for the younger the child, which is a particular concern in the preschool period (Thal \& Katch1996; in Conti- Ramsden \& Durkin, 2012). Through overall assessment, teachers will be able to know which components need more supports in planning the curriculum. As a conclusion, even though language and communication skills encompass few components, these components should be developed together through learning and daily activities in the classroom as well as at home. 
INTERNATIONAL JOURNAL OF ACADEMIC RESEARCH IN BUSINESS AND SOCIAL SCIENCES

Vol. 8, No. 12, Dec, 2018, E-ISSN: 2222-6990 C 2018 HRMARS

\section{RESULTS OF THE STUDY Language and Communication of 2 Years Old}

\begin{tabular}{lc}
\hline Items for Achievement Standard & Percentage \\
\hline Request an object by naming the object. (Communication) & $15.9 \%$ \\
Specifies the name of the object when asked. ( Vocabulary) & $16.9 \%$ \\
Make a sentence using two words. (Syntax) & $17.9 \%$ \\
Follow instructions when requested. (Semantics) & $18.9 \%$ \\
\hline
\end{tabular}

The findings of 2 years old indicate a low performance in all components. This results indicated that majority of children in this study are behind the achievement's standard of 2-year-old.

\section{Language and Communication for 3 Years Old}

\begin{tabular}{lc}
\hline Items for Achievement Standard & Percentage \\
\hline Request an object by specifying an object's name. (Communication) & $51.5 \%$ \\
Pointing and naming objects in the book. (Vocabulary) & $59.7 \%$ \\
Using two to three words in a sentence. (Syntax) & $56 \%$ \\
Taking the right object when requested. (Semantics) & $60.3 \%$ \\
\hline
\end{tabular}

The findings for 3 years old children indicate that $50 \%$ to $60 \%$ attained the achievement's standard. Even though there is increment in the achievement's standard when compared to 2 years old, almost half of the children from this study still did not accomplish the recommended standard.

\section{Language and Communication for 4 Years Old}

\begin{tabular}{lc}
\hline Items for Achievement Standard & Percentage \\
\hline Talk about their drawing. (Communication) & $17.9 \%$ \\
Mention the name of the animal viewed. (Vocabulary) & $33.5 \%$ \\
Using three words in a sentence. (Syntax) & $30.5 \%$ \\
Understand and follow two simple commands. (Semantics) & $45.5 \%$ \\
\hline
\end{tabular}

Findings for 4 years old children indicate that not more than $50 \%$ of children attained the achievement's standard required. Moreover, the communication component shows the lowest achievement that is only $17.9 \%$.

\section{DISCUSSION}

Most young children make significant progress in learning language during the first 4 years of life. Delays or differences in patterns of language acquisition are sensitive indicators of developmental problems (Conti-Ramsden \& Durkin, 2012). On the other hand, the result of the findings showed that children in the study lack behind when compared to the achievement standard for their age group.

For 2 years old children in this study, only 17.9 percent of them has achieved the skills of make a sentence using two words. On the contrary, Jalongo (2014), stated that by two years old, children 
are be able to make a phrase that consist of two or three words utterances. Around their second birthday, they should also be able to combine words together in multiword speech that showed their grammatical knowledge (Conti-Ramsden \& Durkin, 2012). To discuss this matter, information about others factors such as family income, family literacy and neighbourhood disadvantage (Mc Kean et al., 2015) should be examined. However, this research did not include SES as one of the variables in the study that enable researcher to study the factors that affect language development of children in this study.

For children of 3 years old, only 50.6 percent of the children in this study has achieved the skills of using two to three words in a sentence. Even though Conti-Ramsden and Durkin (2012) stated that by 3 years old, children begin to produce longer utterances, combining three or more words. However, there is increment compared to previous year achievement standard that implied, being in the childcare center do effects their language and communication development. Study by Torr and Pham (2016) indicated that teacher-child talk could also play a key role in preschool aged children's language and literacy development. Therefore, it can be presumption, being in the childcare gives advantages that support language and communication development of 3 years old children. A positive association between childcare and development in this study is supported by other researches such as a study on early childcare toward child development by Hansen and Hawkes (2009), and a study by Goldstein, Warde, and Peluso (2013) on publicly supported community based pre-K programs towards children readiness.

For 4 years old children, the result highlighted that the lowest achievement of communication that is $\mathbf{1 7 . 9}$ percents, which is alarming as communication is critical that associate with emotional, social and cognitive development of young children. Result of this study is crucial as stated by Lofland (2013), at the partner stage, children be able to participate in longer conversation. They will make up their own sentences and have short conversations. Therefore, children who are lack of communication skills may struggle to understand or to make themselves understood, have smaller vocabulary, poor listening and social skills. The ability to communicate is an essential life skill for all children and young people in the twenty-first century as it is the core of all social interaction. With effective communication skills, children can engage and thrive. Without them, children will struggle to learn, make friends and interact with the world around them. (Department for Children, Schools and Families, 2008; in Bain, James, \& Harrison, 2015)

Overall results from this study, found that children are behind their achievement standard in all components of language and communication. Nevertheless, lack of communication skills among 4 years old children is alarming, as language and communication is a foundation to other development.

Therefore, the implication of this study focuses on the roles of teachers and parents in fostering young children's language and communication skills. Teachers need to be trained on how to create language rich environment, initiate interactive conversation, and reading time with children in the classroom. On the other hand, parents need to communicate more with their children through daily activities and have reading time as a routine at home (Bain et al., 2015). If teachers and parents work together to support children's language and communication activities at school as well as at 
INTERNATIONAL JOURNAL OF ACADEMIC RESEARCH IN BUSINESS AND SOCIAL SCIENCES

Vol. 8, No. 12, Dec, 2018, E-ISSN: $2222-6990$ C 2018 HRMARS

home, consequently the children's language and communication development will reach the required standards.

\section{CONCLUSION}

Early years is a critical periods in developing children's language and communication skills. Welldeveloped language and communication abilities ensure academic success and social acceptance in the future. Therefore children's language and communication development need to be addressed so as to receive the supports needed. This is due to language and communication which are the predictors of their ability to generate learning information in the future.

\section{CONTRIBUTION}

This study adds to the existing body of literature on language and communication theories for three and four years old children. In Malaysian ECCE context, this study provides a platform from which to consider how early childhood teachers and parents in Malaysia could support English acquisition among three and four years old children while valuing and supporting children's cultural backgrounds.Skills selected for language and communication development were aligned with skills that have been used by other researchers to study language and communication development. This research highlights the levels of language and communication of 4 years old children in Malaysia which has never been done before in the country. It is awakening call to address the results of the research that implied the needs to increase children's language and communication skills.

\section{ACKNOWLEDGEMENT}

This research study is supported by Ministry of Finance (MOF) through the Ministry of Education (MOE) Malaysia, under the National Child Data Center (NCDC) System Sustainability Project, 20180068-106-04. Special thanks to the National Child Development Research Centre (NCDRC), Universiti Pendidikan Sultan Idris (UPSI), for continuous support throughout the research.

\section{REFFERENCES}

Bain, J., James, D., \& Harrison, M. (2015). Supporting communication development in the early years: A practitioner's perspective. Child Language Teaching and Therapy, 31(3), 325-336.

Borovsky, A., Ellis, E. M., Evans, J. L., \& Elman, J. L. (2016). Semantic structure in vocabulary knowledge interacts with lexical and sentence processing in infancy. Child development, 87(6), 1893-1908.

Capone, N. C. (2007). Tapping toddlers' evolving semantic representation via gesture. Journal of Speech, Language, and Hearing Research, 50(3), 732-745.

Christ, T., \& Wang, X. C. (2010). Bridging the vocabulary gap. Young Children, 85.

Clay, M. M. (1993). An observation survey of early literacy achievement. Heinemann, 361 Hanover St., Portsmouth, NH 03801-3912.

Conti-Ramsden, G., \& Durkin, K. (2012). Language development and assessment in the preschool period. Neuropsychology Review, 22(4), 384-401.

Craig, H. K., \& Washington, J. A. (1994). The complex syntax skills of poor, urban, African American preschoolers at school entry. Language, Speech, and Hearing

Services in Schools, 25(3), 181-190. 
INTERNATIONAL JOURNAL OF ACADEMIC RESEARCH IN BUSINESS AND SOCIAL SCIENCES

Vol. 8, No. 12, Dec, 2018, E-ISSN: 2222-6990 @ 2018 HRMARS

Craig, H. K., Connor, C. M., \& Washington, J. A. (2003). Early positive predictors of later reading comprehension for African American students: A preliminary investigation. Language, Speech, and Hearing Services in Schools, 34(1), 31-43.

Goldstein, P., Warde, B., \& Peluso, P. (2013, December). Children's readiness gains in publically funded, community-based pre-kindergarten programs for 4 year olds and preschool for 3 year olds. In Child \& Youth Care Forum (Vol. 42, No. 6, pp. 507-523). Springer US.

Gooden, C., \& Kearns, J. (2013). The Importance of communication skills in young children. Research Brief. Human Development Institute.

Hansen, K., \& Hawkes, D. (2009). Early childcare and child development. Journal of Social Policy, 38(2), 211-239.

Hart, B., \& Risley, T. R. (2003). The early catastrophe: The 30 million word gap by age 3. American educator, 27(1), 4-9.

Jalongo, M. R. (2014). Early childhood language arts. Boston: Pearson.

Lofland, K. (2013). Helping your child develop communication skills. Bloomington IN: Indiana Resource Center for Autism.

Machado, J. M. (2016). Early childhood experiences in language arts: Early literacy $\left(11^{\text {th }}\right.$ ed.). Boston, MA: Cengage Learning.

Malec. A., Peterson, S. S., \& Elshereif, H. (2017), Assessing young children's oral language: Recommendations for classroom practice and policy. Canadian Journal of Education 40, no. 3 (2017): 362-392.

Marchman, V. A., \& Fernald, A. (2008). Speed of word recognition and vocabulary knowledge in infancy predict cognitive and language outcomes in later childhood. Developmental Science, 11(3), 9-16.

McKean, C., Mensah, F. K., Eadie, P., Bavin, E. L., Bretherton, L., Cini, E., \& Reilly, S. (2015). Levers for language growth: Characteristics and predictors of language trajectories between 4 and 7 years. PloS One, 10(8), e0134251.

Neuman, S. B., \& Dwyer, J. (2009). Missing in Action: Vocabulary Instruction in Pre-k. The Reading Teacher, 62, 384-392. http://dx.doi.org/10.1598/RT.62.5.2

Terry, N. P., Mills, M. T., Bingham, G. E., Mansour, S., \& Marencin, N. (2013). Oral narrative performance of African American prekindergartners who speak nonmainstream American English. Language, Speech, and Hearing Services in Schools, 44(3), 291-305.

Torr, J., \& Pham, L. (2016). Educator talk in long day care nurseries: How context shapes meaning. Early Childhood Education Journal, 44(3), 245-254.

Tribushinina, E. (2013). Adjective semantics, world knowledge and visual context: comprehension of size terms by 2-to 7-year-old Dutch-speaking children. Journal of Psycholinguistic Research, 42(3), 205-225. 